\title{
Dolphinfish movements in the Eastern Pacific Ocean of Mexico using conventional and electronic tags
}

\author{
Christopher R. Perle ${ }^{1}$, Stephanie Snyder ${ }^{2}$, Wessley Merten³, Melinda Simmons ${ }^{4}$, Justina Dacey ${ }^{5}$, \\ Ruben Rodriguez-Sanchez ${ }^{6}$, John O'Sullivan ${ }^{7}$ and Sofia Ortega-Garcia ${ }^{6^{*}}$ (D)
}

\begin{abstract}
Background: The dolphinfish, Coryphaena hippurus, is a fast-swimming, predatory fish exhibiting relatively fast growth and early maturation among marine teleosts. It is an important, potentially renewable resource throughout its global subtropical-to-tropical range. Understanding the ecology of this wide-ranging fish is critical to proper fisheries management, but studies have historically depended heavily upon aggregated catch data reported by fisheries. This study uses tagging data to explore finer scale dolphinfish movements in two subregions of the Eastern Pacific Ocean (EPO) - the west coasts of Baja California Peninsula (WBC) and Oaxaca (OAX), Mexico.
\end{abstract}

Results: Adult dolphinfish (fork length $66-129 \mathrm{~cm}$ ) were tagged with conventional ( $n=132$ tags) and electronic tags ( $n=30$ tags, miniPAT) between 2010 and 2014. Recapture rate of conventional tags was $4.5 \%$ with a maximum days of liberty of 141 days (mean $=56 \mathrm{~d}$ ); 20 electronic tags reported but all did so prior to programmed release dates, with days at liberty ranging from 4 to $62($ mean $=24 \mathrm{~d}$ ). Fish remained within the region they were tagged except for six fish tagged in WBC and one in OAX. Latitudinal (WBC) and longitudinal (OAX) extensions of observed fish movements (determined via a novel analytical approach) increased with days at liberty. Despite occasional deep dives (max $262 \mathrm{~m}$ ), fish remained surface oriented with short excursions below the isothermal layer but larger OAX fish (fork length $\left[103 \mathrm{~cm}, 120 \mathrm{~cm}\right.$ ) inhabiting warmer waters (sea surface temperatures $(\mathrm{SST})>\sim 26^{\circ} \mathrm{C}$ ) spent more time below the isothermal layer than smaller fish (fork length $[90 \mathrm{~cm}, 112 \mathrm{~cm}]$ ) inhabiting colder WBC surface waters (SST $>\sim 22^{\circ} \mathrm{C}$ ).

Conclusions: This study reveals movements of dolphinfish that infer regional differences in thermal habitat utilization and displacement over time. This inference evokes questions important to fisheries management regarding the three-dimensional extent of the dolphinfish's realized thermal niche, its population structure, and the spatiotemporal connectivity of its habitats within the multinational EPO. With improved tag retention, longer deployments should capture increasing displacements along observed axes (N/S vs. E/W); the orientation of seasonal displacement axes suggest longer-distance movements would provide opportunities for reproductive mixing via trans-national migrations.

Keywords: Dolphinfish, Electronic tagging, Marine, Movement ecology, Migration, Tracking, WC-GPE3, Eastern Pacific Ocean, Fisheries

*Correspondence: sortega@ipn.mx

${ }^{6}$ Instituto Politécnico Nacional-Centro Interdisciplinario de Ciencias Marinas, Av, IPN S/N Col. Playa Palo de Santa Rita, La Paz, B.C.S, Mexico

Full list of author information is available at the end of the article

\section{Background}

The common dolphinfish (Coryphaena hippurus) is an epipelagic predatory fish inhabiting tropical and subtropical waters in all oceans [1]. Globally, dolphinfish 
constitute primarily non-target catch in large-scale longline and purse seine commercial fishing operations [2], substantial proportions of landings among artisanal fleets [3], and prized catches in regional recreational fisheries [4, 5]. Although habitat use and distribution patterns define availability and susceptibility to fishing pressure [6], few studies have reported direct observations of dolphinfish movements and behaviors.

Increasing popularity of dolphinfish as an easily accessible, high-protein food item has raised concerns of local depletions due to targeted and/or incidental catches throughout its range [7]. For example, with the exception of tropical tunas, dolphinfish is the most common species taken when purse seiners set on drifting fish aggregating devices (DFADs), a fishing practice now commonly employed worldwide [8]. Due to suspected under-reporting of high incidental catches during these operations and differing federal management strategies, dolphinfish was recently listed by the US as a species potentially vulnerable to Illegal, Unreported, and Unregulated (IUU) fishing worldwide [9]. Comprehensive fisheries management plans (FMPs) for nations harvesting dolphinfish in the Eastern Pacific Ocean (EPO) have to date only been established in Ecuador and Peru [10, 11], despite the exploitation of this potentially renewable marine resource by the 11 countries in the region (all members of the Inter-American Tropical Tuna Commission (IATTC)) [12]. Although dolphinfish constitute more than half of the large pelagic catch of some member nations [3], comprehensive EPO-wide stock assessments for dolphinfish have also not been published to date, further raising questions about the status of the population [13, 14]. Low population structure $[15,16]$ likely results in some measure of correspondence between seasonal abundances and movements of dolphinfish across national jurisdictions, yet no integrated, multinational FMP exists for this species. Increasing landings and new policy initiatives underscore an urgent need to improve knowledge of the scales and impacts of the various fisheries that take dolphinfish in the EPO, as well as the understanding of the movements of individual fish that may connect breeding populations throughout the region, data that are currently lacking [9].

Globally, the dolphinfish is known to undertake longdistance seasonal migrations within home ranges limited poleward from the equator by the $20{ }^{\circ} \mathrm{C}$ surface isotherm to both the north and south [17]. In the Atlantic, electronic and conventional tagging and genetic studies suggest that dolphinfish are regionally connected in an annual western/central Atlantic migration circuit, based on low population structure between sampled sites and observed movements between locations that would increase gene flow $[4,5,18]$. Additional studies have documented that dolphinfish strongly associated with floating surface macroalgae, flotsam, and Fish Aggregating Devices (FADs), with both homing and high levels of fidelity ( $>15$ days) observed in the Indian Ocean [19-23]. A study combining commercial and recreational fisheries data determined that while sea surface temperature is a strong correlate of dolphinfish catches, surface chlorophyll- $a$ is not [24].

In terms of vertical movements, short duration tagging studies in the western central Atlantic Ocean, western Pacific Ocean, and the Gulf of California, Mexico, report diel shifts in behavior from shallow depths during the day to deeper depths (i.e., below the surface isothermal layer) at night, perhaps in response to movements of epipelagic and mesopelagic prey, or to reduce risk of predation [18, 25-27]. The same diel vertical behavior was noted in both farm-reared and wild dolphinfish in marginal waters of the East China Sea [28]. In the oceanic waters of the $E P O$, long-term fisheries-independent observations of seasonal, horizontal and vertical movement patterns of dolphinfish have not been described to date.

Seasonal patterns of dolphinfish movements in the EPO have been estimated by tracking fishing effort and catches. Peak abundances in southern fisheries (Peru and Ecuador) occur from October to April (austral springsummer) [3, 29], while peak abundances in northern fisheries (Mexico) occur from September to November (boreal summer-autumn) [30]. Seasonal latitudinal movements apparently correspond with physical changes in oceanic conditions, e.g., northerly range limits extend beyond the coast of Baja California Norte to as far north as Oregon, US, in warm El Niño years [31,32]. While it has been suggested that the migratory behaviors of dolphinfish are strongly related to sea surface temperature $[1,33]$, this relationship has not been analyzed in detail anywhere within the EPO. Behavioral responses to changing surface currents, temperature regimes and/or prey abundance patterns may also influence both shortterm movements and long-term migrations of this active, epipelagic predator.

Advancing knowledge of dolphinfish movements within regions of the EPO can help improve regional management and provide foundational underpinnings for an integrated multinational fisheries management plan by, e.g., identifying critical habitat parameters, the timing and extent of migration cycles and the presence or absence of migration corridors. This study tracks movements of dolphinfish in Mexico by employing both conventional and electronic tagging techniques (Floy ${ }^{\circledR}$ and Mini-PAT ${ }^{\circledR}$, respectively), using a novel analytical approach for evaluating the proprietary daily global positions ("geolocations") produced by WC-GPE $3^{\circledR}$, an online algorithm provided to end-users by tag manufacturer 
Wildlife Computers ${ }^{\circledR}$. The research presented aims to increase the resolution of the realized thermal niche of dolphinfish within and beyond a broad range of sea surface temperatures $\left(20-30^{\circ} \mathrm{C}\right)$ [16] while also investigating the movements of dolphinfish as they relate to thermal habitat availability in order to evaluate the potential for inter-regional mixing in the EPO.

\section{Results}

\section{Deployments, recoveries and tag performance}

A total of 162 tags (30 electronic and 132 conventional) were deployed on dolphinfish from 2010 to 2014 in oceanic waters off the west coast of Mexico. Four tagging trips took place late summer/early fall offshore of the coast of Baja California Peninsula (denoted WBC, hereafter) and two late winter/early spring trips were

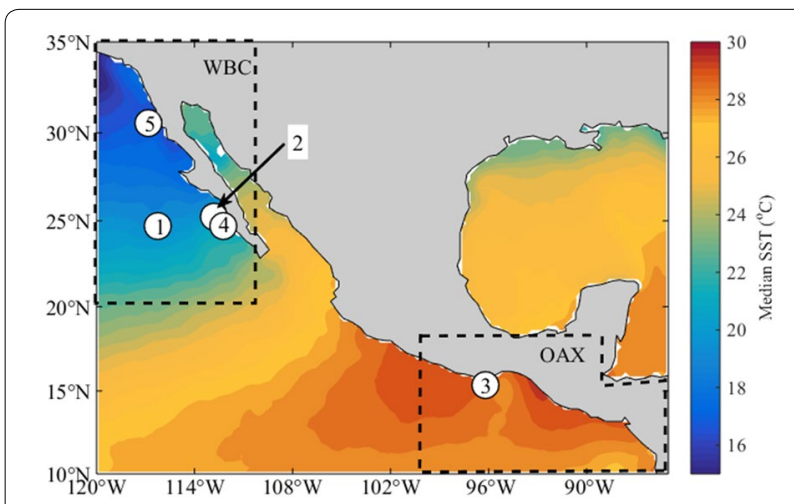

Fig. 1 Tag deployment locations (denoted by white circles) within the study areas (denoted by dashed boxes). The numbers correspond with the trips described in Table 1 and the background colors correspond to median SST during the years of the study $(2010,2011$, 2013, and 2014) undertaken offshore of the Mexican state of Oaxaca (OAX, hereafter) (Fig. 1; Table 1). Ninety-four percent of all tags were deployed in WBC (fork length range: $66-112 \mathrm{~cm}$ ) with the remaining 6\% deployed in OAX (100-129 cm; Table 1, Fig. 1).

All fish in the study were mature adults according to published length at maturity data (females: $L_{50}=48.38 \pm 0.84 \mathrm{~cm}, \quad L_{100}=64 \mathrm{~cm}$ and males: $L_{50}=50.57 \pm 2.16 \mathrm{~cm}, L_{100}=67 \mathrm{~cm}$ ) [34]. Sex ratios of the tagged fish were fairly even overall, with 79 males and 83 females tagged (0.95:1); however, more males (19 fish) than females (11 fish) were tagged with electronic tags $(1.7: 1)$. Although previous studies have shown sexdependent length frequency distributions [34], female fish did not differ significantly in size $(88 \mathrm{~cm}[83.3,93])$ from the male fish tagged in this study $(89 \mathrm{~cm}[82,93]$, Wilcoxon rank-sum, $p=0.96$ ). However, there were regional differences in size as fish with reporting electronic tags in WBC were significantly smaller $(95 \mathrm{~cm}$ [92 cm, $101 \mathrm{~cm}])$ than those in OAX $(113 \mathrm{~cm}[105,116.5]$, Wilcoxon rank-sum, $p=0.001$ ).

Overall, $4.5 \%$ of conventional tags were recovered and $67 \%$ of electronic tags reported with two of those fish also being recaptured; however, recovery rates and tag performance varied by year and by sex (Table 1). Males were twice as likely to be recaptured than females; however, there was no difference in electronic tag reporting rates between males and females (Table 1). One of the deployed electronic tags did not report, but its numbered leader (\#5015 in Table 2) was recovered, thus counting as a conventional tag recovery and a nonreporting electronic tag. One fish is represented twice in Table 2, as its electronic tag (\#111535) reported before the fish and its conventional tag (\#5056) were recaptured. All electronic tags released prior to their

Table 1 Deployment trip information

\begin{tabular}{|c|c|c|c|c|c|c|c|}
\hline \multirow[t]{2}{*}{ Date } & \multirow[t]{2}{*}{ Map location } & \multicolumn{3}{|c|}{$\begin{array}{l}\text { Number of electronic tags } \\
\text { Reported/deployed (percent reported) }\end{array}$} & \multicolumn{3}{|c|}{$\begin{array}{l}\text { Number of conventional tags } \\
\text { Recaptured:deployed (percent recaptured) }\end{array}$} \\
\hline & & Total & Females & Males & Total & Females & Males \\
\hline \multicolumn{2}{|c|}{ Baja California Peninsula (WBC) } & $12 / 20^{\mathrm{a}}(60 \%)$ & $5 / 9(56 \%)$ & $7 / 11^{a}(64 \%)$ & $6 / 132(4.5 \%)$ & $1 / 72(1.4 \%)$ & $5 / 60(8.3 \%)$ \\
\hline Sep 30-Oct 4, 2010 & 1 & $5 / 5(100 \%)$ & $4 / 4(100 \%)$ & $1 / 1(100 \%)$ & $0 / 78(0 \%)$ & $0 / 56(0 \%)$ & $0 / 22(0 \%)$ \\
\hline Sep 29, 2011 & 2 & $0 / 5^{\mathrm{a}}(0 \%)$ & $0 / 2(0 \%)$ & $0 / 3^{\mathrm{a}}(0 \%)$ & $6 / 54(11 \%)$ & $1 / 16(6 \%)$ & $5 / 38(13 \%)$ \\
\hline Jul 20, 2013 & 4 & $5 / 6(83 \%)$ & $1 / 1(100 \%)$ & $4 / 5(80 \%)$ & 0 & 0 & 0 \\
\hline Sep 21-29, 2014 & 5 & $4 / 4(100 \%)$ & $2 / 2(100 \%)$ & $2 / 2(100 \%)$ & 0 & 0 & 0 \\
\hline \multicolumn{2}{|c|}{ Oaxaca, Mexico (OAX) } & $8 / 10^{a}(80 \%)$ & $2 / 2(100 \%)$ & $6 / 8^{a}(75 \%)$ & 0 & 0 & 0 \\
\hline Mar 6-7, 2013 & 3 & $4 / 4^{\mathrm{a}}(100 \%)$ & 0 & $4 / 4^{\mathrm{a}}(100 \%)$ & 0 & 0 & 0 \\
\hline Feb 11, 2014 & 3 & $4 / 6(66 \%)$ & $2 / 2(100 \%)$ & $2 / 4(50 \%)$ & 0 & 0 & 0 \\
\hline
\end{tabular}

Map location references locations in Fig. 2

a Denotes that one of the electronic tags was recaptured 
Table 2 Deployment and recapture information

\begin{tabular}{|c|c|c|c|c|c|c|c|c|}
\hline & Tag number & Deployment date & Recovery date & $\begin{array}{l}\text { Fork } \\
\text { length } \\
(\mathrm{cm})\end{array}$ & Sex & Days at liberty & $\begin{array}{l}\text { Displacement } \\
\text { rate } \\
\left(\mathrm{km} \mathrm{day}^{-1}\right)\end{array}$ & $\begin{array}{l}\text { Estimated } \\
\text { speed } \\
\left(\mathbf{k m ~ d a y}^{-1}\right)\end{array}$ \\
\hline \multirow[t]{18}{*}{ Baja California Sur (WBC) } & 62145 & $3-O c t-10$ & 7-Oct-10 & 95 & $\mathrm{~F}$ & 4 & 45.2893 & $59.2[31.8,84.3]$ \\
\hline & 132984 & 29-Sep-14 & $4-O c t-14$ & 112 & M & 5 & 22.841 & $32.8[19.0,78.2]$ \\
\hline & 111534 & 29-Sep-14 & 6-Oct-14 & 102 & M & 7 & 24.8793 & $14.5[5.9,55.2]$ \\
\hline & 111532 & 20-Jul-13 & 28-Jul-13 & 93 & M & 8 & 36.1919 & $55.2[42.6,72.4]$ \\
\hline & 111533 & 20-Jul-13 & 28-Jul-13 & 90 & M & 8 & 17.2715 & $80.8[37.9,107.5]$ \\
\hline & 62148 & $3-O c t-10$ & $12-$ Oct-10 & 95 & $F$ & 9 & 8.1457 & $6.1[2.8,18.4]$ \\
\hline & 62147 & 3-Oct-10 & $16-$ Oct-10 & 91 & M & 13 & 15.441 & $12.3[4.5,24.1]$ \\
\hline & $812^{a, b}$ & 29-Sep-11 & 14-Oct-11 & 82 & M & 15 & 57.7071 & - \\
\hline & 62143 & $2-O c t-10$ & $27-O c t-10$ & 90 & $\mathrm{~F}$ & 25 & 15.3501 & $13.2[7.8,25.2]$ \\
\hline & 111524 & 20-Jul-13 & 15-Aug-13 & 106 & M & 26 & 14.4953 & $32.4[23.2,58.2]$ \\
\hline & $829^{a, b}$ & 29-Sep-11 & 27-Oct-11 & 94 & $\mathrm{~F}$ & 28 & 24.1102 & - \\
\hline & 62142 & 2-Oct-10 & 31-Oct-10 & 93 & $\mathrm{~F}$ & 29 & 13.79 & $15.0[7.3,24.9]$ \\
\hline & $5015^{\mathrm{a}}$ & 29-Sep-11 & 28-Oct-11 & 102 & M & 29 & 13.9893 & - \\
\hline & $806^{a, b}$ & 29-Sep-11 & 7-Nov-11 & 89 & M & 39 & 17.3099 & - \\
\hline & 111525 & 20-Jul-13 & 2-Sep-13 & 98 & $\mathrm{~F}$ & 44 & 3.5003 & $28.9[15.8,59.0]$ \\
\hline & $111522^{b}$ & 20-Jul-13 & 15-Sep-13 & 100 & M & 57 & 12.8832 & $29.2[16.2,47.8]$ \\
\hline & $824^{a, b}$ & 29-Sep-11 & 3-Dec-11 & 86 & M & 65 & 13.317 & - \\
\hline & $823^{a, b}$ & 29-Sep-11 & 12-Dec-11 & 86 & M & 74 & 11.6974 & - \\
\hline \multirow[t]{9}{*}{ Oaxaca, Mexico (OAX) } & 111530 & 7-Mar-13 & 12-Mar-13 & 115 & M & 5 & 52.9865 & $18.8[16.8,58.4]$ \\
\hline & 111531 & 6-Mar-13 & 13-Mar-13 & 100 & M & 7 & 31.7146 & $71.8[58.7,90.0]$ \\
\hline & 111528 & 7-Mar-13 & 19-Mar-13 & 120 & M & 12 & 30.568 & $21.9[8.4,61.8]$ \\
\hline & 111535 & 6-Mar-13 & 19-Mar-13 & 113 & M & 13 & 25.1631 & $41.6[11.4,68.4]$ \\
\hline & 128932 & 11-Feb-14 & 25-Mar-14 & 118 & M & 42 & 3.4949 & $19.4[5.8,48.2]$ \\
\hline & 128934 & 11-Feb-14 & 30-Mar-14 & 107 & $F$ & 47 & 8.0329 & $30.1[15.6,66.5]$ \\
\hline & 128931 & 11-Feb-14 & 6-Apr-14 & 103 & M & 54 & 9.9843 & $28.0[14.3,53.9]$ \\
\hline & 128936 & 11-Feb-14 & 14-Apr-14 & 113 & $\mathrm{~F}$ & 62 & 5.4108 & $27.3[14.4,55.8]$ \\
\hline & $5056^{a, b}$ & 6-Mar-13 & 25-Jul-13 & 113 & M & 141 & 11.1662 & - \\
\hline
\end{tabular}

a Denotes conventional tags

b Denotes tags that were recaptured outside of the study area in which they were tagged

pre-programmed dates with days at liberty ranging from 4 to 62 days (mean $=24$ days). These deployment times for electronic tags were shorter on average than for recovered conventional tags which ranged from 15 to 141 days (mean $=56$ days). Deployment duration for both conventional and electronic tags did not correlate with fish length (Pearson Correlation, $p=0.58$ ), sex (Wilcoxon rank-sum, $p=0.53$ ), or region (Wilcoxon rank-sum, $p=0.28$ ). However, fish tagged in 2014 with a modified tag attachment (see "Methods") did have significantly longer deployment durations (58 days [48.75, 92]) than fish tagged prior to 2014 (12.5 days [8, 25.75], Mann-Whitney $U$-test, $p=0.002)$. Due to reduced deployment durations from premature releases, temporal coverage of the electronic tagging data is limited to the months of July-October in WBC and FebruaryMarch in OAX.

\section{Horizontal and vertical movements}

Conventional tag recoveries from longer duration deployments showed fish movements out of the tagging region (6 out of 7 recoveries), while electronic tags generally reported after shorter deployments on fish that remained within the original tagging area-with the exception of 111522 (Fig. 2). Net displacements between deployment locations and recovery sites ranged from 73.3 to $1574 \mathrm{~km}$ $($ mean $=434 \mathrm{~km})$. Location estimations (see "Methods" for description of techniques) had the highest scores (i.e., best sea surface temperature data agreement between tag observations and those derived from model locations) when the initial animal speed input parameter ranged from 1.75 to $3.75 \mathrm{~m} \mathrm{~s}^{-1}\left(3 \mathrm{~m} \mathrm{~s}^{-1}\left[2.5 \mathrm{~m} \mathrm{~s}^{-1}, 3.31 \mathrm{~m} \mathrm{~s}^{-1}\right]\right)$. The initial input parameter does not dictate the daily speeds, but rather provides an envelope of speeds available to the model. Median estimated daily displacements along the estimated tracks (derived only for electronic 

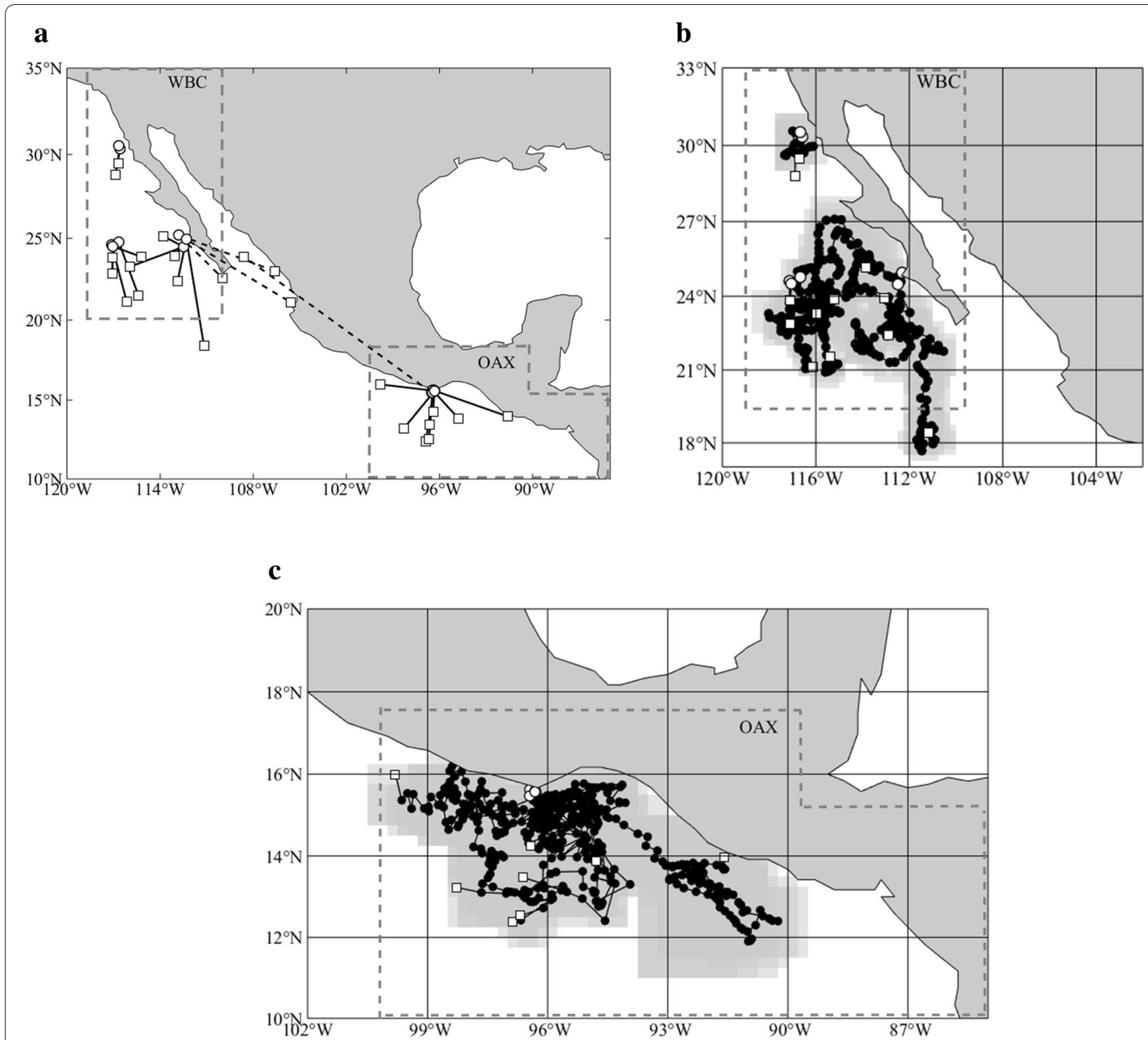

Fig. 2 Maps of horizontal movement of dolphinfish showing a deployment and recovery/reporting locations of conventional (dashed lines) and electronic tags (solid lines) as well as $\mathbf{b}$, c estimated tracks from electronic tagged dolphinfish in $\mathbf{b}$ the WBC region and $\mathbf{c}$ the OAX region. In all panels, deployment locations are denoted by circles while recovery/reporting locations are denoted by squares. In $\mathbf{b}$, c, estimated electronic tag 12-h locations are represented by black circles and surrounded by an area encompassing the $95 \%$ likelihood of each location

tags) ranged from 6.1 to $80.8 \mathrm{~km} \mathrm{day}^{-1}$ (Table 2). Overall displacement rates (for all tags from their deployment location to recovery location) ranged from 3.50 to $57.71 \mathrm{~km} \mathrm{day}^{-1}$.

Daily speeds standardized by body length did not significantly vary by region (Wilcoxon rank-sum, $p=0.79$ ) or by sex (Wilcoxon rank-sum, $p=0.34$, Table 2). Latitudinal and longitudinal extent of displacements differed as a function of days at liberty and region (Fig. 3). All fish exhibited an expansion of their latitudinal habitat range with more days at liberty, with WBC fish having a greater range in latitude with longer deployment durations (Spearman rank correlation, OAX: slope $=0.04$, $p=0.02$; WBC: slope $=0.05, p=0.0001$ ). Fish from both regions showed greater increases in longitudinal range with longer deployment durations (Spearman rank correlation, OAX: slope $=0.08, p=0.0009$; WBC: slope $=0.09$, $p=0.0005)$.

Over the course of the study, only seven fish-six from WBC (one electronic) and one from OAX (identified from the leader of an electronic tag) - moved outside the region in which it was tagged. However, daily movements 

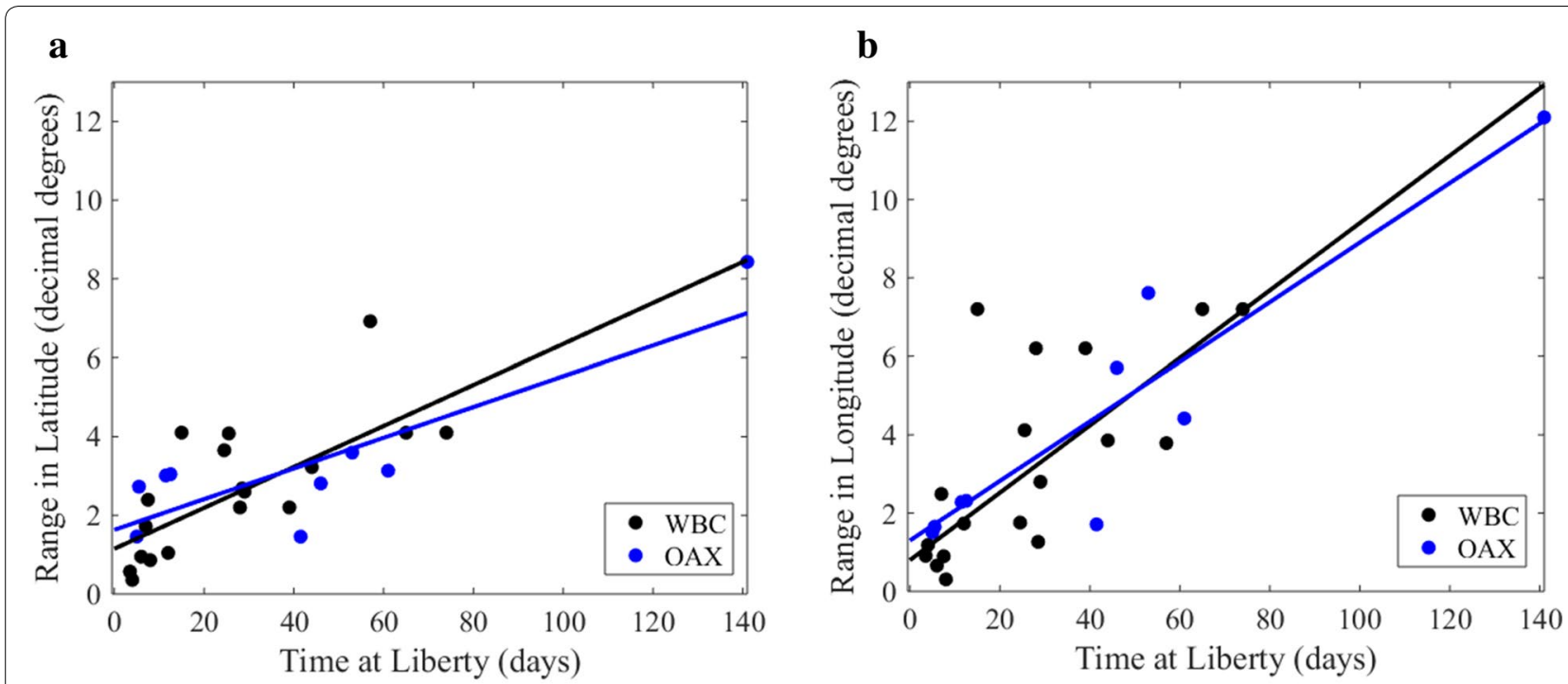

Fig. 3 Home range extents in $\mathbf{a}$ latitude and $\mathbf{b}$ longitude as a function of time at liberty. Region is denoted by color (black=WBC and blue =OAX)

indicated southerly tendencies during summer and autumn for WBC fish and westerly tendencies from early to late spring for OAX fish. Several WBC fish appeared to have moved south in response to seasonal sea surface temperature changes as the tags released and one fish from OAX was recaptured in WBC in summer after a premature electronic tag release in spring.

The vast majority of diving was restricted to surface waters, with $68.9 \%$ of total reported time-series observations $(140,042$ of 203,264$)$ occurring in the shallowest $5 \mathrm{~m}$. For most fish, daily median depths were shallower than $5 \mathrm{~m}$ for the majority of their time at liberty (Table 3 ). In general, WBC fish spent a greater percentage of time in the top $5 \mathrm{~m}(84.6 \%$ [61.6\%, 94.1\%]) and dove to greater daily maximum depths (i.e., maximum observed depth per day; $59 \mathrm{~m}$ [39 m, $84.5 \mathrm{~m}])$ than OAX fish $(61.1 \%$ [35.1\%, 88.5\%]; $36.5 \mathrm{~m}$ [26.5 m, $45 \mathrm{~m}]$ ), Wilcoxon ranksum, $p<0.001$ ).

Although dolphinfish spent the majority of their time in the top $5 \mathrm{~m}$, their diving varied significantly on days when they dove below the isothermal layer depth. Even in our small dataset, we found the same individual fish would exhibit both "traditional" (deeper dives during daytime) and reverse diel diving (for example tag 111522: Fig. 4). This plasticity in habitat utilization patterns was similar in fish across regions and sexes. Fish from both regions were observed more frequently in shallow depths, but also made frequent shallow dives, and occasional deep dives to below $100 \mathrm{~m}$ with maximum depth of $262 \mathrm{~m}$ (Table 3). Overall, maximum daily depth was significantly greater during the day than at night for WBC fish, whereas OAX fish did not exhibit significant diurnal difference in vertical movements (Table 3). Although WBC fish exhibited deeper maximum daily diving depths, the variance in daily diving depths-measured here as the daily interquartile range-was greater in the OAX fish $(10.1[0.5,17])$ than the WBC fish $(1.5[0.5$, 14]; Wilcoxon rank-sum, $p=0.03$ ). In both regions, most dolphinfish showed more variance in daily diving depths at night than during the day (Table 3 ).

\section{Thermal habitat}

Thermal habitat availability differed between the two regions during the respective tagging deployments. In OAX, sea surface temperatures are warmer throughout the year than in WBC (Fig. 5a). In WBC, the lowest sea surface temperatures occur in February through March while the highest occur in August through October. On the other hand, OAX does not exhibit a strong annual cycle; sea surface temperatures are relatively stable intraannually between 26 and $31^{\circ} \mathrm{C}$.

Vertical thermal habitat availability also differs between the regions. The isothermal layer depth in WBC was twice as deep as that in OAX (Fig. 5b). These regional patterns resulted in significantly different thermal habitats for fish in WBC versus OAX, with WBC fish experiencing colder sea surface temperatures and deeper isothermal layers than OAX fish (Table 4). However, the timing of tag deployments had the effect of minimizing observed differences in sea surface temperatures between the two regions (Fig. 5a).

Differences in diving corresponded with differences in thermal habitat availability between regions. As a result of these regional differences, OAX fish experienced 
Table 3 Statistical summary of vertical movements

\begin{tabular}{|c|c|c|c|c|c|c|c|}
\hline \multirow[t]{2}{*}{ Fish ID } & \multirow{2}{*}{$\begin{array}{l}\text { Number } \\
\text { of full days }\end{array}$} & \multicolumn{2}{|c|}{ Median depth (m) } & \multicolumn{2}{|l|}{ Maximum depth (m) } & \multicolumn{2}{|c|}{ Interquartile depth range (m) } \\
\hline & & Day & Night & Day & Night & Day & Night \\
\hline WBC & 139 & $1[0.5,2.4]$ & $1[0.5,4.5]$ & $45.5[23,79.8]$ & $37[5.5,65.4]$ & $0.5[0.5,5.8]$ & $0.5[0.5,20.4]$ \\
\hline 62142 & 27 & $5.5[3,19.4]$ & $1[1,3.4]$ & $39.5[32,80.3]$ & $12[5.625,67.1]$ & $8[4.6,20]$ & $0.5[0.5,14.4]$ \\
\hline 62143 & 24 & $1[0.5,2.5]$ & $2.625[0.5,42]$ & $85[75.8,92.5]$ & $64.5[4.5,78]$ & $6.3[0.3,54.3]$ & $18.9[0.3,38]$ \\
\hline 62145 & 3 & $2[2,2.4]$ & $31[8.5,32.5]$ & $91[78.6,104.9]$ & $77[64.6,91.6]$ & $2.5[1.8,2.9]$ & $13.5[6.8,16.7]$ \\
\hline 62147 & 12 & $1[0.5,1.5]$ & $1[0.5,4]$ & $57[34,74.3]$ & $39[3.8,51.8]$ & $0.5[0.5,2.3]$ & $0.5[0.5,15.4]$ \\
\hline 62148 & 8 & $1.5[1.5,1.5]$ & $1.5[1.5,1.5]$ & $32.3[11,42.8]$ & $9[3.3,57.3]$ & $0.5[0.5,1]$ & $0.5[0.5,0.5]$ \\
\hline 111522 & 17 & $0.5[0.5,0.5]$ & $3.5[1.4,7.9]$ & $23[18.8,39]$ & $56.5[39.8,70]$ & $0[0,0.5]$ & $21.5[7.2,36.8]$ \\
\hline 111524 & 7 & $1[1,1.4]$ & $1[0.6,1]$ & $40.5[29.4,84.1]$ & $38.5[6.9,47.9]$ & $1[0.5,1.5]$ & $0.5[0.5,8.8]$ \\
\hline 111525 & 17 & $0.5[0.5,0.6]$ & $0.5[0.5,1]$ & $51.5[42.3,82]$ & $28[2,36.5]$ & $0.5[0.5,0.5]$ & $0.5[0.5,1.0]$ \\
\hline 111532 & 7 & $1.5[1,2.3]$ & $12.8[1.1,21.8]$ & $43[29.1,59.5]$ & $66[25.9,73]$ & $0.5[0.5,4.1]$ & $20.5[0.5,31.8]$ \\
\hline 111533 & 7 & $1[0.5,1]$ & $1[0.5,1]$ & $51[38.5,56.9]$ & $28.5[28.5,38.1]$ & $1.5[0.6,2.4]$ & $1[0.6,9.3]$ \\
\hline 111534 & 6 & $0.5[0.5,0.5]$ & $0.75[0.5,1]$ & $1.3[1,17.5]$ & $1.5[1,39]$ & $0.5[0.5,0.5]$ & $0.5[0.5,0.5]$ \\
\hline 132984 & 4 & $0.5[0.5,0.5]$ & $0.5[0.5,0.5]$ & $1[1,1]$ & $1[1,27.8]$ & $0[0,0]$ & $0[0,0.5]$ \\
\hline OAX & 164 & $1[0.5,15.5]$ & $3[0.5,17.9]$ & $29.5[11.3,38.5]$ & $33.5[23,40]$ & $3[0.5,10.9]$ & $9.3[0.5,16.2]$ \\
\hline 111528 & 10 & $1[0.5,8.5]$ & $1[1,5.5]$ & $1.3[1,38.5]$ & $1.25[1,34.5]$ & $0.5[0.5,15]$ & $0.5[0,9.5]$ \\
\hline 111530 & 4 & $0.5[0.5,7.5]$ & $9[0.5,20.8]$ & $12[1,27]$ & $17.25[1,45.5]$ & $6[0,14]$ & $4.8[0,17.3]$ \\
\hline 111531 & 6 & $0.5[0.5,0.5]$ & $0.75[0.5,1]$ & $1[1,1]$ & $1.25[0.5,45]$ & $0[0,0]$ & $0.5[0,3.9]$ \\
\hline 111535 & 11 & $0.5[0.5,1]$ & $1[0.5,1]$ & $1.5[1,1.5]$ & $1.5[1.5,1.5]$ & $0.5[0.5,0.5]$ & $0.5[0.5,0.5]$ \\
\hline 128931 & 38 & $24[9,27]$ & $20[16,24]$ & $36.8[33.5,42]$ & $34.5[29,40]$ & $6.8[4.5,12]$ & $10.8[7,16.8]$ \\
\hline 128932 & 29 & $1[0.7,15.5]$ & $1[1,4.4]$ & $31[24,37]$ & $32[26,36.5]$ & $3.4[0.5,9.9]$ & $13.5[0.7,17.1]$ \\
\hline 128934 & 32 & $0.5[0.5,0.75]$ & $0.75[0.5,10]$ & $28.3[15.5,37.8]$ & $28.75[21.5,38.5]$ & $0.5[0,8.3]$ & $9.2[0,16.3]$ \\
\hline 128936 & 34 & $0.5[0.5,10.5]$ & $2.25[0.5,15.5]$ & $26.5[21.5,36]$ & $37[31,45.5]$ & $4.1[0,14.9]$ & $11.1[0,17.5]$ \\
\hline
\end{tabular}

Fish with statistically different ( $p<0.05$, Wilcoxon sign-rank test) vertical distributions between day and night are in italic

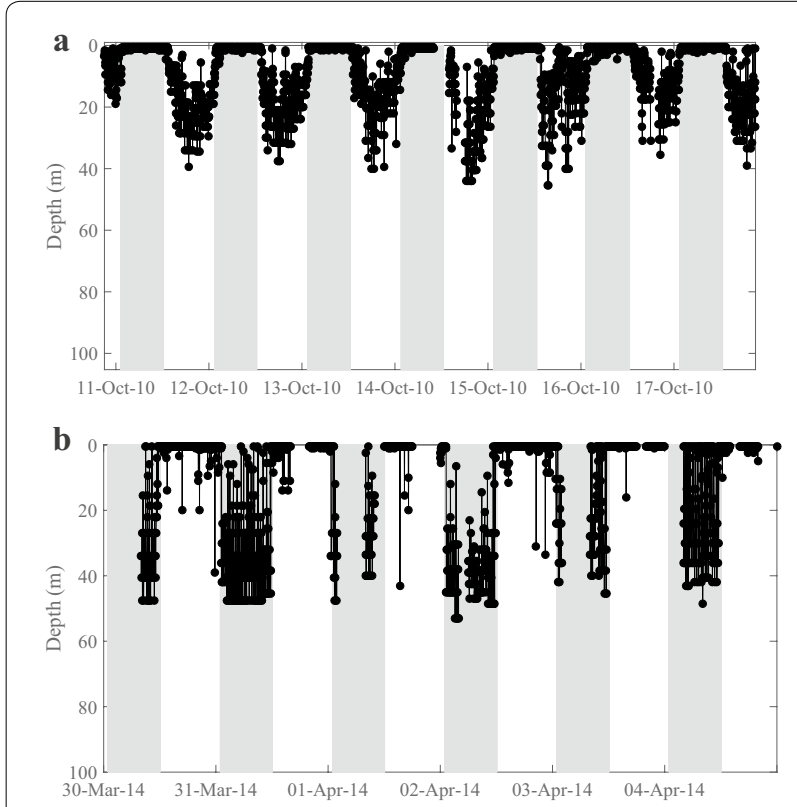

Fig. 4 Examples of differences in a daytime diving and $\mathbf{b}$ nighttime diving from an individual fish (Tag 111522). The black lines represent the fish's position while the gray bars denote nighttime significantly warmer median daily temperatures $\left(27.2^{\circ} \mathrm{C}\right.$ $\left.\left[26.2^{\circ} \mathrm{C}, 28.2^{\circ} \mathrm{C}\right]\right)$ than WBC fish $\left(22.4^{\circ} \mathrm{C}\left[22{ }^{\circ} \mathrm{C}, 23.1^{\circ} \mathrm{C}\right]\right.$, Wilcoxon rank-sum, $p<0.001$ ) even though fish in both regions spent most of their time within the isothermal layer (Table 4). Dolphinfish experienced water temperatures ranging from 11.7 to $30.0^{\circ} \mathrm{C}$ (WBC) and from 12.5 to $32{ }^{\circ} \mathrm{C}$ (OAX). Differences between the observed median daily temperatures and sea surface temperatures in the WBC (SST-median temperature) were $0.04{ }^{\circ} \mathrm{C}$ $[0,0.14]$, while fish in OAX recorded greater differences between their median daily temperatures and sea surface temperatures with differences of $0.37^{\circ} \mathrm{C}[0.12,1.1]$. These differences result from differences in vertical habitat use between fish in WBC and OAX regions. Fish in the OAX spent less time at the surface than fish in the WBC, and this correlates with differences in SST-with fish exhibiting less surface oriented distributions in waters with SST greater than $26^{\circ} \mathrm{C}$ (Fig. 6).

\section{Discussion}

This study reports the horizontal and vertical activity of mature dolphinfish observed through the use of conventional tags and PSATs in the EPO off the west coasts of Baja California Peninsula and Oaxaca, Mexico. 

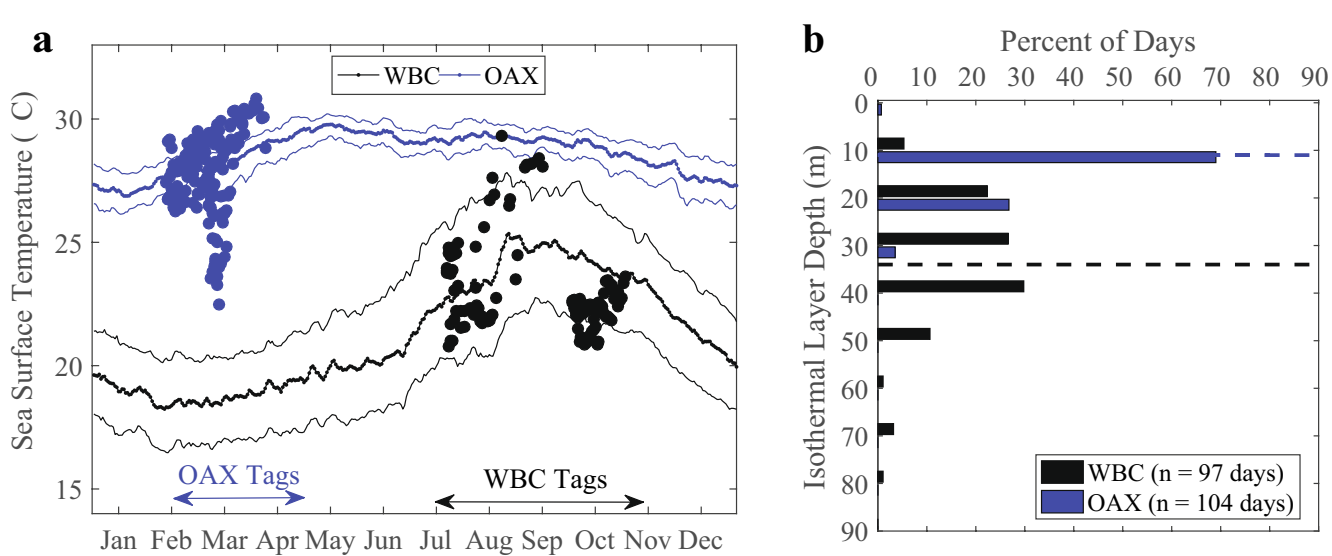

Fig. 5 Regional patterns in a sea surface temperature and $\mathbf{b}$ depth of the thermal mixed layer experienced by WBC and OAX tags. In $\mathbf{a}$, the middle line with points represent the median while the lower and upper values represent the 25 and 75 percentiles. Observed SST values from the tags are in circle markers. Arrows denote temporal range of our tagging dataset for fish in WBC and OAX. In $\mathbf{b}$, the dashed lines represent the median ILD for each region

Table 4 Statistical summary of thermal habitat

\begin{tabular}{|c|c|c|c|c|c|c|}
\hline \multirow[t]{2}{*}{ Fish ID } & \multicolumn{2}{|c|}{ Number of days } & \multirow{2}{*}{$\begin{array}{l}\text { Sea surface } \\
\text { temperature }\left({ }^{\circ} \mathrm{C}\right)\end{array}$} & \multirow{2}{*}{$\begin{array}{l}\text { Isothermal layer depth } \\
\text { (m) }\end{array}$} & \multicolumn{2}{|c|}{ Percent time in isothermal layer } \\
\hline & SST & $\overline{\text { ILD }}$ & & & Day & Night \\
\hline WBC & 139 & 97 & $22.4[22.1,23.3]$ & $34[18.4,42.6]$ & $93[68.1,100]$ & $92.6[58.1,100]$ \\
\hline 62142 & 27 & 13 & $22.4[22.3,22.6]$ & $43[36.8,44.4]$ & $100[81.3,100]$ & $100[80.2,100]$ \\
\hline 62143 & 24 & 20 & $22.2[21.2,23.0]$ & $38.5[35.3,48]$ & $77.4[53.8,98.9]$ & $90.6[45.1,98.6]$ \\
\hline 62145 & 3 & 3 & $22.3[22.2,22.3]$ & $38.5[36.6,41.5]$ & $97.7[84.3,98.2]$ & $71.1[66,90.5]$ \\
\hline 62147 & 12 & 9 & $22.3[21.4,22.3]$ & $45.5[41.8,59.5]$ & $99.0[97.4,99.6]$ & $100[97.1,100]$ \\
\hline 62148 & 8 & 3 & $22.4[22.2,22.4]$ & $44[43.6,55.3]$ & $100[100,100]$ & $100[78.1,100]$ \\
\hline 111522 & 17 & 16 & $27.0[25.4,28.1]$ & $15[11.3,17]$ & $75.5[66.1,91.4]$ & $46.7[36.9,55.2]$ \\
\hline 111524 & 7 & 6 & $22.2[21.3,22.3]$ & $31.3[20,39.5]$ & $67.7[64.9,81]$ & $55.6[50.2,89.5]$ \\
\hline 111525 & 17 & 14 & $21.9[21.7,22.4]$ & $26[21,32.5]$ & $82.8[61.4,88.9]$ & $88.9[61.5,100]$ \\
\hline 111532 & 7 & 5 & $24.6[24.5,24.8]$ & $7.5[7,13.9]$ & $98.3[68.7,99.9]$ & $44.3[33.3,100]$ \\
\hline 111533 & 7 & 5 & $23.7[23.1,23.9]$ & $10.5[9.8,12.8]$ & $92[86.5,98.3]$ & $93.5[75.0,98.8]$ \\
\hline 111534 & 6 & 2 & $22.5[22.3,22.6]$ & $33[27,39]$ & $100[100,100]$ & $100[99.3,100]$ \\
\hline 132984 & 4 & 1 & $22.4[22.0,22.6]$ & 31.5 & 100 & $100[95.3,100]$ \\
\hline OAX & 164 & 104 & $28.1[26.8,29.0]$ & $11[7.8,16]$ & $82.5[29.2,100]$ & $68.0[32.4,100]$ \\
\hline 111528 & 10 & 1 & $24.2[23.5,26.1]$ & 7.5 & 100 & 100 \\
\hline 111530 & 4 & 0 & $26.2[25.6,27.0]$ & - & 100 & 100 \\
\hline 111531 & 6 & 1 & $25.7[25.0,26.5]$ & 24 & 100 & 100 \\
\hline 111535 & 11 & 0 & $26.2[24.2,26.8]$ & - & 100 & 100 \\
\hline 128931 & 38 & 32 & $29.4[29.0,30.2]$ & $12[9.3,15]$ & $12.4[8.8,84.5]$ & $19.9[10.8,29.6]$ \\
\hline 128932 & 29 & 18 & $27.2[26.8,27.7]$ & $10[6.5,13]$ & $88.9[43.5,100]$ & $71.5[56.6,100]$ \\
\hline 128934 & 32 & 22 & $28.3[27.7,28.8]$ & $12.5[9,18]$ & $87[56.4,100]$ & $77.2[49.8,100]$ \\
\hline 128936 & 34 & 30 & $28.6[28.2,29.2]$ & $9.5[7,19]$ & $62.9[29.6,83.5]$ & $59[20.5,77.2]$ \\
\hline
\end{tabular}

Fish with statistically different $(p<0.05$, Wilcoxon sign-rank test) diving behavior between day and night are in italic

While fork lengths were similar for males and females, larger, mostly male, fish were tagged in OAX than in WBC, which had a roughly even sex ratio. Alejo-Plata, et al. [34] provided evidence of seasonal sex-based segregation in OAX, finding sex ratios skewed to more females than males in Apr-May and more males than females in Nov-Dec. The higher tag recovery rates of male dolphinfish versus females in this study may 

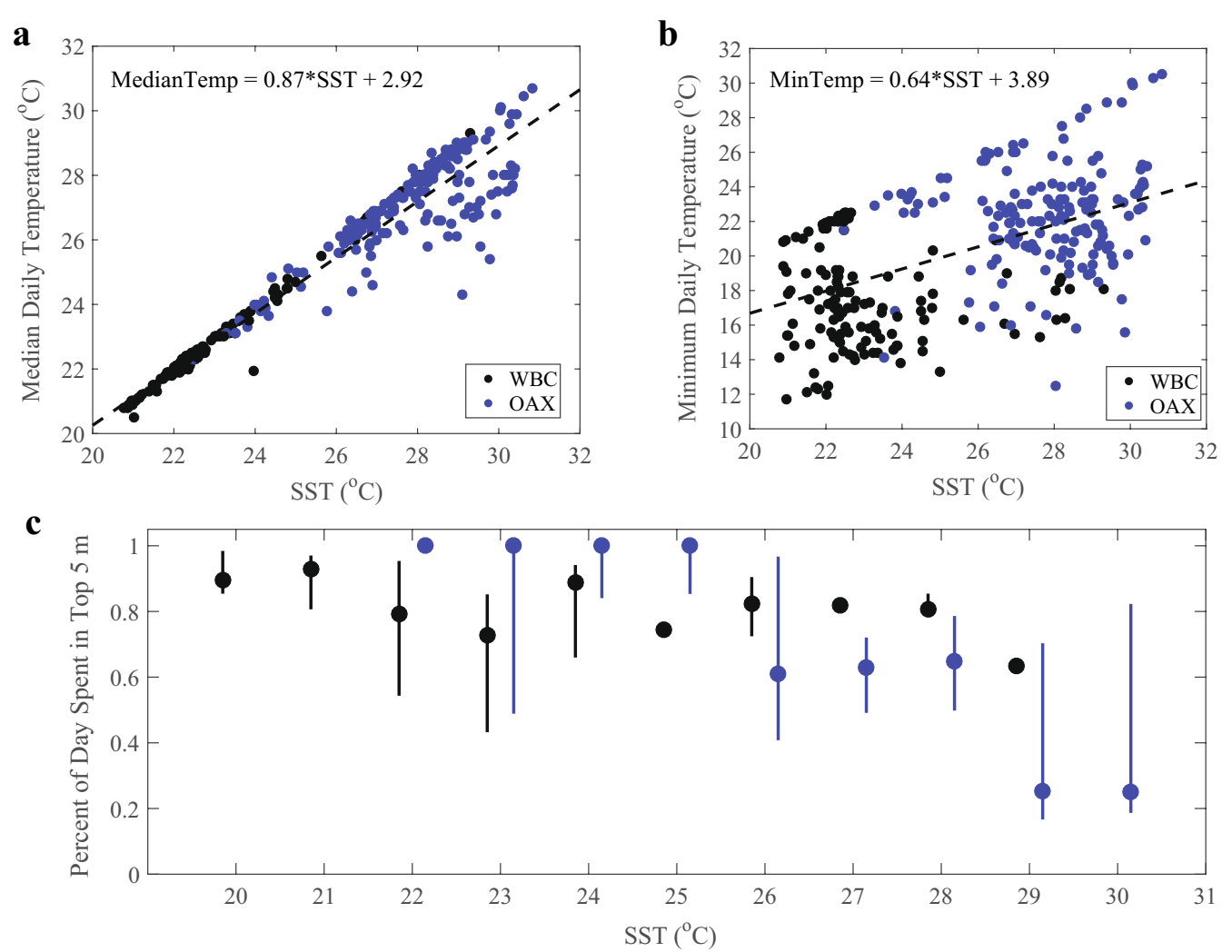

Fig. 6 Dive distribution with respect to sea surface temperature. The dots represent the median while the lines represent the 25th and 75th percentiles of percent time in the top $5 \mathrm{~m}$ per day within $1^{\circ} \mathrm{C}$ SST bins

reflect sex-based segregation or suggest that males are more susceptible to fisheries than females; however, this result may also be a random effect due to the relatively small sample size.

While premature release of all electronic tags resulted in limited observations of geographic movements, the potential for longer migrations is discernible both in conventional tag recoveries and the horizontal movement data revealed by the electronic tags' daily position estimates. The correlation between tagging durations and displacement in fish from both regions imply movements over longer tagging durations may indeed show connectivity between distant regions. The orthogonal axes of movements observed (N/S for WBC vs E/W for OAX) suggest a possible mechanism for mixing of fish via a putative annual migration circuit from OAX west and then north to WBC in summer/fall, then south and east back to OAX in winter. However, longer duration movements are needed to confirm how or if mixing occurs. The directionality of movements may be influenced by the availability of thermal habitats, surface currents, the presence of shallow oxygen minimum layers, or a combination of factors that make certain habitats less suitable than others, seasonally.
Observed vertical movements largely within the isothermal layer with occasional deep excursions are typical of dolphinfish, although the maximum depth of $262 \mathrm{~m}$ is the deepest depth yet reported for the species. As reported in other studies, shallow marine habitat use may be attributed to prey location $[18,35]$, association with flotsam [36] (such as tree trunks, and macroalgal mats which commonly occur throughout the study regions), or bioenergetic conservation by remaining in preferred thermal conditions $[25,37]$. Deep excursions may reflect foraging or predation avoidance behaviors.

Although only "reverse" diel diving (deeper dives at night) has been observed in other dolphinfish studies $[18,25-28,37]$, the "traditional" diel diving observed here may be a result of ephemeral changes in the thermal structure of the water column, presence or absence of predators, and/or changes in the distribution and availability of prey items. It is also possible that the longer duration tag deployments in this study reveal a plasticity and variability in movements not observed in previous studies with shorter tag deployments.

Changes in degree of surface orientation (e.g., basking) suggest that some diving and migratory movements may be in response to regional-scale differences in thermal 
habitat. Fish in the WBC region experienced significantly colder surface waters and deeper isothermal layer depths than fish in the OAX. This correlated with more surface oriented distributions and deeper dives in the WBC fish than in the OAX fish. Furthermore, fish in the OAX that experienced waters with sea surface temperatures greater than $26{ }^{\circ} \mathrm{C}$ spent more time at depth, perhaps to reduce their experienced median water temperature. These changes in vertical movements may limit the realized ecological niche space of dolphinfish and may drive migratory movements between the two regions, for example, when the waters in the WBC region seasonally cool during boreal winter months (not observed in this study).

Our observations in WBC (though limited temporally in our small dataset) support published dolphinfish distribution models based on fisheries dependent catch data in the region. Marín-Enríquez et al. [38] modeled the probability of dolphinfish occurrence in this region from incidental catch data taken from tuna purse seine fisheries as a function of different environmental parameters. The study predicted dolphinfish occurrence in greatest abundances in a distant offshore oceanic zone of the EPO during late spring, an area that extended northeastward through summer to the west coast of Baja California peninsula. Peak abundance off WBC occurred annually in summer and fall several months after intense winter and spring upwelling occurred allowing dolphinfish's preferred prey (pelagic red crab, Pleuronocodes planipes) and optimal thermal conditions $\left(23-28^{\circ} \mathrm{C}\right)$ to establish. Dolphinfish were modeled to retract from the WBC region later in the year when cold water upwelling events returned, movements that are reflected in the southerly movement axis apparent in the WBC fish data presented here.

This seasonal abundance pattern in WBC is also supported by dolphinfish catch rates by the Los Cabos sportfishing fleet, which have been reported to be higher west of the capes of the Baja California Sur during September [39]. Additional support can be found in the catch statistics from the south of Cabo Corrientes, which have been shown to be maximal in the fourth quarter of the year [40]. Similar fisheries data are needed for nearshore and offshore areas of the OAX region, as it appears to be a gap in commercial and recreational fishing or reporting, perhaps due to its remoteness and lack of accessibility to ports and populations.

\section{Conclusions}

This study provides new information on the dynamic movements of dolphinfish in the EPO while supporting previously reported large-scale thermal habitat constraints to dolphinfish abundance and distribution patterns. While geographic axes of movement provide evidence on which to base hypothetical mixing routes, regional differences in thermal structure present environmental variability (and corresponding changes in diving) to migrating fish. However, temporal limitations in tracking durations and high uncertainty bounding daily geolocation estimates restrict analysis of potential migration routes within or beyond the study region. Improvements in tag retention are critical to obtaining deployment lengths that span summer and winter months, when region-connecting migrations may occur. While basking behavior could potentially cause early releases, our results did not show a difference in deployment duration between WBC fish that spent more time basking than OAX fish. However, ongoing improvements in tag attachment techniques did significantly increase deployment durations over the course of this study.

The new geolocation algorithm used in this study, WCGPE3, allowed the incorporation of uncertainty into model selection and geolocation estimation. The methodology provided here is critical to this study, and useful to future WC-GPE3 users, but is substantially a sensitivity test of a single model for a single species. As advances in geolocation algorithms continue to be made, accuracybased error estimates, though difficult to obtain and often limited in sample size or conditions, are as necessary as precision-based likelihoods. In addition, comparison of the various available geolocation model outputs (for example, see Braun [41]) along with estimates of their respective accuracy bounds is an important area of research. Finally, increasing the cost effectiveness of GPS based electronic tags is perhaps a more favorable way to solve the "track-finding" problem of light-based geolocation $[42,43]$.

Future studies of dolphinfish in the EPO should strive to provide the animal movement and genetic data necessary to improve the regional and international management of the species as a potentially renewable natural and economic resource. Our data indicate that dolphinfish movement patterns may differ not only between distant global habitats (such as those reported in the northwest Atlantic and Pacific Oceans [4, 26]), but also within subregions of the EPO. These differences may be indicative of stock structure and reproductive isolation, but are insufficient as proof of such. More directed and geographically diverse studies are needed to establish or refute reproductive connectivity of dolphinfish within and between the eleven EPO nations that economically exploit dolphinfish and other large marine predators.

Considering the economic importance of dolphinfish as a resource throughout Baja Mexico, mainland Mexico and Central America, it is important to note the migration of dolphinfish out of the WBC region as indicated by 
four conventional tag recaptures more than $500 \mathrm{~km}$ away from their tagging locations, and one out of the OAX region, a $1500 \mathrm{~km}$ displacement (Fig. 2a, Table 2). It is imperative that actual migration routes, inclusive of dates of regional exit and entry, be determined by future studies that emphasize increasing the duration of electronic tag deployments (for example, see Perle [44]). Oceanic migration routes may introduce dolphinfish to unregulated fishing pressure in international waters or those of other EPO nations or alternatively provide them with escapement from intensive coastal fishing. Understanding long-distance, directed migrations would also help scientists determine if a single, panmictic population of dolphinfish exists in the EPO.

Finally, if prey availability does indeed predict dolphinfish behaviors in addition to thermal habitat characteristics, improved regional-scale information on forage fish abundance and distribution would be needed to improve predictions of their movements. Our electronic tag recovery data, with $100 \%$ premature releases and 30\% non-reporting tags, suggest that adult dolphinfish may also be ecologically important prey of larger fish (see Additional file 1). Epipelagic feeding strategies expose dolphinfish to recreational sport fishing vessels and other larger marine predators, while deeper feeding strategies expose them to different types of commercial gear. A greater understanding of where and when these behaviors prevail would help in the management of their various fisheries and the maintenance of their abundance locally, regionally and globally.

\section{Methods}

\section{Fishing and tagging protocol}

To assess dolphinfish movements and habitat preferences in the EPO waters of Mexico, fish were tagged in two regions: offshore of west coast of Baja California Peninsula (WBC: $20-35^{\circ} \mathrm{N}, 110-118.0^{\circ} \mathrm{W}$ ) and farther south in the coastal waters of Oaxaca, Mexico (OAX: 10-18 N, $85-100^{\circ} \mathrm{W}$; Fig. 1, Table 1). Dolphinfish tagging in WBC occurred in conjunction with the Monterey Bay Aquarium's Animal Care Division field collection trips. Although adult dolphinfish were targeted in both regions, fishing methodology differed as a result of the variability of available fishing vessels and expertise. Tag models and tag applications were consistent in both regions-with the exception of modifications (see below) to improve tag retention in the fall of 2014.

Dolphinfish were caught either by rod and reel (WBC) or longline (OAX). Rod and reel fishing targeted dolphinfish associated with floating kelp. The fishing rigs included Seaguar ${ }^{\circledR} 25-40 \mathrm{lb}$ test monofilament and Owner ${ }^{\circledR}$ circle-style hooks (size 1/0) baited with live sardines (Sardinops sagax). Longlines were set according to local practices by participating artisanal fishermen aboard small pangas, spanned approximately $5 \mathrm{~km}$ in total length and soaked for $7 \mathrm{~h}$ with checks every $2 \mathrm{~h}$. Hooks were baited with a mix of live jacks $(4-6 \mathrm{~cm}$; Family Carangidae) or pieces of black skipjack (Euthynnus lineatus).

Upon capture, dolphinfish selected for tagging were either landed onboard the vessel with a nylon sling (WBC) or held tightly alongside the panga (OAX). To minimize stress in the landed fish, their eyes were covered with a wet towel, and gills irrigated with oxygenated seawater to minimize stress. In both areas, the tagging procedure lasted 3-5 min. Size and sex were recorded. Sizes were reported as median [25th percentile, 75 th percentile] by sex and by region.

Fish were tagged with conventional, plastic dart tags (Floy Tag Inc., Seattle, Washington, USA) and/or with electronic pop-up satellite tags (PSAT; MiniPAT, Wildlife Computers Inc., Redmond, WA, USA), generally according to size, with fish larger than $90 \mathrm{~cm}$ selected for electronic tagging. As female and male dolphinfish approximately $90 \mathrm{~cm}$ in length weigh approximately $5.8 \mathrm{~kg}$ and $6.32 \mathrm{~kg}$, respectively, the tag $(60 \mathrm{~g})$ was at most approximately $1 \%$ of the fish's body weight [45]. Electronic tags included a numbered tether that remained attached to the fish after the electronic tag released. For the majority of the study, conventional and electronic tags were inserted into the dorsal musculature of smaller fish to the depth of pterygiophores. While conventional tag application was unaltered through the study, electronic tag application in WBC in fall 2014 was changed from previous deployment years to improve tag retention and, therefore, deployment duration.

Prior to fall 2014, the electronic tags were attached to nylon anchors with numbered, shrink-wrapped $300 \mathrm{lb}$ $(136 \mathrm{~kg})$ test monofilament leaders and inserted into the dorsal musculature as described above. However, in fall 2014, this design was altered (following Merten et al. [4]). The new method included a $300 \mathrm{lb}(136 \mathrm{~kg})$ monofilament leader $\left(\mathrm{Momoi}^{\circledR}\right.$ extra hard), $40 \mathrm{~cm}$ in length, anchored to each tag with an appropriately sized stainless-steel crimp. The unattached end of the monofilament leader was inserted into a $15.2 \mathrm{~cm}$ long hollow stainless-steel, cannula (.125 cm OD, .093 ID) with $45^{\circ}$ beveled sharp edge. After a small incision was made midline above the spine and below the dorsal ridge with a surgical scalpel, the applicator tube was used to push the leader entirely through the fish anteriorly from the point of insertion at an angle of $45^{\circ}$, parallel to the midline of the fish. After the monofilament leader passed through the fish, it was anchored to the tag leader with another stainless-steel crimp and two affixed $1 / 2$ in. diameter, circular laminated vinyl backing plates (Floy Tag $^{\circledR}$ ). This 
resulted in approximately $\sim 4 \mathrm{~cm}$ of monofilament leader between the electronic tag and fish.

\section{Electronic tag programming protocol}

Electronic tags were programmed to release from the fish by corroding a sacrificial link after either 60 or 90 days. During deployment, electronic tags recorded depth, ocean temperature and light at $3 \mathrm{~s}$ intervals. However, complete archival records are only available if a tag is physically recovered and capable of being downloaded. During this study, no electronic tags were physically recovered. Therefore, data archived during tag deployments were either subsampled or summarized, transmitted post-release via satellites and accessed via the Wildlife Computers $^{\circledR}$ data portal (http://mywildlifecomputers. com). Data strings of temperature and depth time-series were subsampled from the archival data and transmitted in packets of ten data points per $150 \mathrm{~s}$; binned summaries of time-at-depth $[0,5,10,15,20,30,40,50,75,100$, $150,>150 \mathrm{~m}]$ and time-at-temperature $[4,16,18,20,22$, $24,26,27,28,29,30,>30^{\circ} \mathrm{C}$ ] used 12 bins to bound and center fish depth and temperature utilization, respectively (e.g., see Additional file 2). Light and mixed layer temperature daily summaries were transmitted using default settings. Transmission priorities were set to favor the light data necessary for geolocation (WC-GPE3). Statistical analyses reported here are restricted to the transmitted time-series data and were conducted in the MATLAB computing environment [46].

To assess survivorship and tag performance, recoveries, reporting rates, and early releases were calculated as a function of region, sex, and size. Tags that did not report may have failed due to one of several undiscernible events-e.g., tag/battery failure, user error upon deployment, recovery by fishermen with subsequent intentional or unintentional disabling of transmitting capability, growth of fouling organisms that impact antenna or wet/ dry sensor orientation, or animal mortality causing rapid sinking of the tag to destructive depths in deep ocean waters. Tags reporting early may be the result of "tagshedding", animal or tag predation resulting in free floating tags, or vertical distribution-based triggering of early release logic (e.g., extended surface orientation). Extensive analysis of factors impacting tag reporting success are interesting, but beyond the scope of this report.

\section{Movement analysis}

Semi-daily estimated geographic positions ("geolocations") for electronic tags were calculated using proprietary software ("WC-GPE3") from tag manufacturer, Wildlife Computers ${ }^{\circledR}$. WC-GPE3 employs a state-space model to incorporate information from tags (i.e., light curves and surface temperature), satellites (i.e., surface temperature), and an animal movement (speed) model to create a grid of position likelihoods at a spatial resolution of $0.25^{\circ}$ [47]. The model allows for a user defined initial parameter for animal speed. This parameter influences the spatial range at which the model will examine potential animal locations given the animal's prior location. Based on the high-performance swimming of dolphinfish $[48,49]$, WC-GPE3 was run with animal speeds from 1 to $5 \mathrm{~m} \mathrm{~s}^{-1}$ at increments of $0.25 \mathrm{~m} \mathrm{~s}^{-1}$.

Increasing the initial value for animal speed has two innate impacts on the model: (i) it increases model scores due to the increase in potential location "matches" and (ii) it increases the areas of uncertainty because the animal can move over a greater spatial scale. To address this trade-off, the best model run was chosen as the model that (i) produced the lowest areas of uncertainty and (ii) had overall scores above the following cut-off criteria (s_crit):

$$
s_{-} \text {crit }=.95\left(s \_ \text {max }-s \_ \text {min }\right)+s \_ \text {min }
$$

where $s_{-}$max is the maximum score and $s_{-} \min$ is the minimum score (Fig. 7). Area of uncertainty was calculated as the area of the grid cells that contained $95 \%$ of the cumulative uncertainty per observation, excluding the first and last days of deployment. Scores were generated internally by WC-GPE3 and represent the average fit of the tag's observations (tag light curves and sea surface temperatures) with those of the model-derived locations (pers. comm., Suzanne Kohin).

Trends in overall horizontal movements were examined as both total displacements and estimated speeds. Distance was calculated using the Haversine formula (great-circle distance) and the estimated latitudinal and longitudinal coordinates. Daily displacement rates $\left(\mathrm{km} \mathrm{day}{ }^{-1}\right)$ were calculated by calculating the distance and days at liberty between release and recapture/pop-up locations for conventional and electronic tags, respectively. For geolocations, daily speeds $\left(\mathrm{km} \mathrm{day}^{-1}\right)$ were estimated using the centroid of the daily area of uncertainty. These speeds were summarized and presented as median [25th percentile, 75th percentile] unless otherwise stated. Patterns in habitat extent or range-measured by range of latitude (or longitude) as a function of days at liberty-were examined for potential of migration or mixing between the two regions using robust linear regression.

Maximum and median depths were calculated per day observed. Depth range of the vertical habitat was also calculated as the interquartile range of daily depths. Proportion of time basking was estimated as the proportion of daytime observations in the upper $5 \mathrm{~m}$. Because dolphinfish have been shown to exhibit diel diving in the western central Atlantic [4], diving patterns were also examined 


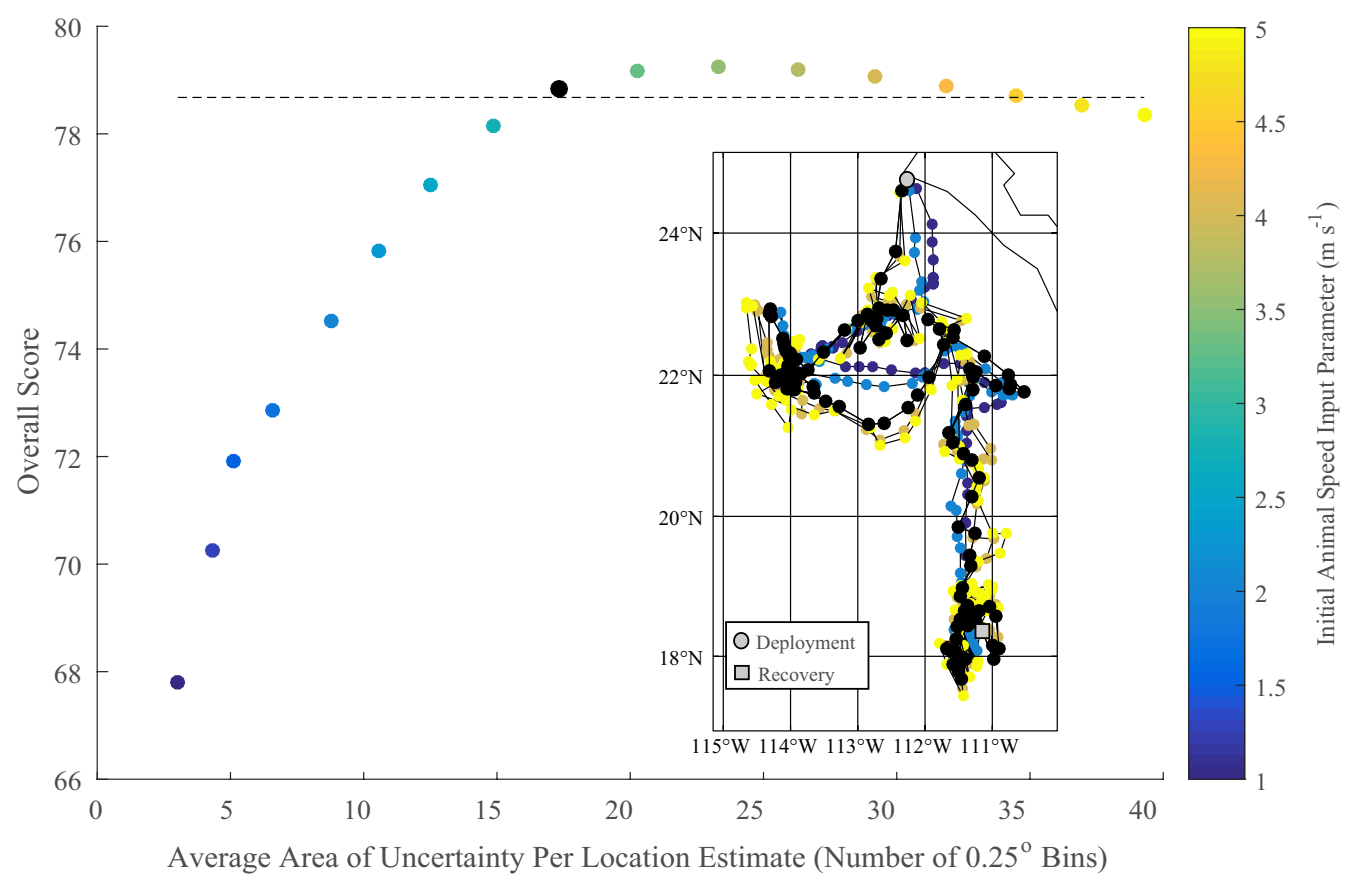

Fig. 7 Example of model run selection for tag number 111522 which was at liberty for 57 days. Multiple iterations of the WC-GPE3 were run to select an optimal value of animal speed for the model input. a Potential tracks colored by animal speed parameter with black track representing the track used in the final analysis. $\mathbf{b}$ The trade-off between model optimization (cut-off represented by dashed line) and the size of the area of uncertainty with the data colored by animal speed parameter and the black dot representing the model used in the final analysis

diurnally. Nighttime and daytime hours were determined using tag recorded and transmitted light curves, and the hour around sunrise and sunset were excluded. Significance of diurnal comparisons was evaluated using the Wilcoxon sign-rank test.

Analyses were conducted per fish and patterns in vertical movements were examined within the context of tagging region. As there are temporal gaps in the subsampled, transmitted temperature and depth time-series, diurnal diving was only examined in 24 -h periods where there were depth data for greater than $50 \%$ of each day and night. Values are presented as median [25th quartile, 75th quartile] unless otherwise stated. When comparing across regions, daily values were used to capture variability both among and within fish. Significance of differences between regions was determined using the Wilcoxon rank-sum test unless otherwise stated.

\section{Analysis of thermal habitat}

A main focus of this study is to place observations of movements within the context of the animal's utilization of the available thermal habitat. Thermal habitat utilization was characterized by daily median, minimum and sea surface temperatures determined via electronic tagging data. The percent time in the isothermal layerILD, defined as the maximum depth at which the water temperature remains within $0.8{ }^{\circ} \mathrm{C}$ of the sea surface temperature (average temperature of the top $5 \mathrm{~m} \mathrm{[50])-}$ was calculated per fish for both day and night. Thermal habitat utilization of OAX fish and WBC fish was then compared using the Wilcoxon sign-rank test. Thermal habitat utilization for a day was only determined if data for greater than $50 \%$ of the day was reported (as with depth data).

To assess thermal habitat availability, sea surface temperatures were compiled for the time period of this study (2010-2014). The custom SST climatology for the time period and region of this study was built from the NOAA high-resolution $\left(0.25^{\circ} \times 0.25^{\circ}\right)$ blended analysis of daily SST data product (OISSTv2 [51]). The annual climatology presented here is the median and interquartile range of sea surface temperature observations in each of the deployment regions per day of year.

\section{Supplementary information}

Supplementary information accompanies this paper at https://doi. org/10.1186/s40317-020-00217-9.

Additional file 1. Depth time series from a recent model (2018) electronic tag that released due to pre-programmed "depth release logic" at $1400 \mathrm{~m}$. This is evidence of possible predation that may have been responsible for earlier tag versions to not report, such as the 10 non-reporting tags in this study. 
Additional file 2. Example of all received transmitted satellite data for fish 111522. No single data source is complete for the duration of the deployment, but collectively, fluctuations in behavior are illustrated. All analyses focused on transmitted time series data.

\section{Abbreviations}

WBC: West of Baja California Peninsula, MEX; OAX: West of Oaxaca, MEX; IQR: Interquartile range; EPO: East Pacific Ocean; WCGPE3: Wildlife Computers Global Position Estimator 3; SST: Sea surface temperature; ILD: Isothermal layer depth; PSAT: Pop-up satellite archival tag.

\section{Acknowledgements}

The authors would like to thank the captain and staff of the FN Shogun, fisherman Francisco Galguera of Puerto Angel, Oaxaca, MEX, assisting staff of the Monterey Bay Aquarium, and Heidi Dewar of National Oceanographic and Atmospheric Association, Suzy Kohin of Wild life Computers and Toby Patterson of Commonwealth Scientific and Industrial Research Organisation of Australia for guidance and suggestions. SOG and RRS are fellowship recipients of Comision de Operacion y Fomento de Actividades Academicas (COFAA). Thanks also to Mexican authorities from INAPESCA (Instituto Nacional de Pesca) for help during the administrative process.

\section{Authors' contributions}

SOG, JOS, and RRS conceived and design this research. CRP composed and edited text, managed tags pre deployment and tag data post deployment. SMS analyzed tag data, composed, and edited figures, tables and text. WM and MPS composed and edited text. MPS and JD tracked, confirmed and edited references and text, JOS and RR-S tagged all fish, RR-S and SOG edited text and provided fisheries expertise. All authors read and approved the final manuscript.

\section{Funding}

This study was funded in full by the Monterey Bay Aquarium (Grant no. SIP-2014-RE/076).

\section{Availability of data and materials}

The datasets used and/or analyzed during the current study are available from the corresponding author on reasonable request.

\section{Ethics approval and consent to participate}

All organisms were tagged under authority of the Comisión Nacional de Pesca y Acuacultura permit numbers DAPA/2/130910/044423, DAPA/2/030511/01246, and DGOPA-DAPA-01595/13. Research methods and protocols were approved by the Monterey Bay Aquarium's Research Oversight Committee.

\section{Consent for publication}

Not applicable.

\section{Competing interests}

The authors declare that they have no competing interests.

\begin{abstract}
Author details
1 Florida State College at Jacksonville, 9911 Old Baymeadows Rd., Jacksonville, FL 32256, USA. ${ }^{2}$ Thomas More University, 333 Thomas More Parkway, Crestview Hills, KY 41018, USA. ${ }^{3}$ Dolphinfish Research Program, Beyond Our Shores Foundation, Newport, RI 02840, USA. ${ }^{4}$ Marine Science Research Institute, Jacksonville University, 2800 University Blvd N, Jacksonville, FL 32211, USA. ${ }^{5}$ Institute of Food \& Agricultural Sciences, University of Florida, 543350 US Highway 1, Callahan, FL 32011, USA. ${ }^{6}$ Instituto Politécnico Nacional-Centro Interdisciplinario de Ciencias Marinas, Av, IPN S/N Col. Playa Palo de Santa Rita, La Paz, B.C.S, Mexico. ${ }^{7}$ Monterey Bay Aquarium, 886 Cannery Row, Monterey, CA 93940, USA.
\end{abstract}

Received: 14 January 2020 Accepted: 6 August 2020

Published online: 20 August 2020

\section{References}

1. Palko BJ, Beardsley GL, Richards, WJ. Synopsis of the biological data on dolphin-fishes, Coryphaena hippurus Linnaeus and Coryphaena equiselis Linnaeus. NOAA Tech Rep, vol. 443; 1982.

2. Whoriskey S, Arauz R, Baum JK. Potential impacts of emerging mahi-mahi fisheries on sea turtle and elasmobranch bycatch species. Biol Conserv. 2011;144(6):1841-9. https://doi.org/10.1016/j.biocon.2011.03.021.

3. Martínez-Ortiz J, Aires-da-Silva A, Lennert-Cody C, Maunder M. The Ecuadorian artisanal fishery for large pelagics: species composition and spatio-temporal dynamics. PLOS ONE. 2015;10:e0135136. https://doi. org/10.1371/journal.pone.0135136.

4. Merten W, Appeldoorn R, Hammond D. Movements of dolphinfish (Coryphaena hippurus) along the US east coast as determined through mark and recapture data. Fish Res. 2014;151:114-21. https://doi.org/10.1016/j. fishres.2013.10.021.

5. Merten W, Appeldoorn R, Hammond D. Movement dynamics of dolphinfish (Coryphaena hippurus) in the northeastern Caribbean Sea: evidence of seasonal re-entry into domestic and international fisheries throughout the western central Atlantic. Fish Res. 2016;175:24-34.

6. Hampton J, Sibert J, Kleiber P, Maunder M, Harley S. Decline of Pacific tuna populations exaggerated? Nature. 2005;434:E1-2. https://doi. org/10.1038/nature03581 (discussion E2).

7. IUCN: The IUCN red list of threatened species. Version 2017-3. 2017. http://www.iucnredlist.org. Accessed 15 Dec 2017.

8. Fonteneau A, Chassot E, Bodin N. Global spatio-temporal patterns in tropical tuna purse seine fisheries on drifting fish aggregating devices (DFADs): taking a historical perspective to inform current challenges. Aquat Living Resour. 2013;26:37-48. https://doi.org/10.1051/alr/2013046.

9. Magnuson-Stevens Fishery Conservation and Management Act (MSA); Seafood Import Monitoring Program, 50 C.F.R. §300.324(b)(2); 2016.

10. Abo-Tubikh NAS. Status and improvement of artisanal fisheries in Manabi province, Ecuador: a case study. Int J Fish Aquat Stud. 2014;2(2):47-54.

11. Solis PG, Aleman JC, Lujan C, Morales J. Guia de Buenas Practicas Pesquera. Peru: Ministerio de la Produccion Peru; 2015. p. 1-60.

12. Valero JL, Aires-da-Silva A, Maunder MN, Minte-Vera C, Martínez-Ortiz J, Torrejón-Magallanes EJ, Carranza MN. Exploratory management strategy evaluation (MSE) of Dorado (Coryphaena hippurus) in the south Eastern Pacific Ocean. In: Inter-Amer Trop Tuna Comm Sci Adv Comm., Seventh Meeting; 2016.

13. Aires-da-Silva A, Maunder M. Status of bigeye tuna in the eastern Pacific Ocean in 2012 and outlook for the future. In: Inter-Amer Trop Tuna Comm Stock Assess Rep, vol. 14. 2014. pp. 31-185.

14. Aires-da-Silva A, Valero JL, Maunder MN, Minte-Vera C, Lennert-Cody C, Román MH, Martínez-Ortiz M, Torrejón-Magallanes EJ, Carranza MN. Exploratory stock assessment of dorado (Coryphaena hippurus) in the southeastern Pacific Ocean. In: Inter-Amer Trop Tuna Comm Tech doc. SAC-07-06a(i) 2016. http://www.iattc.org/Meetings/Meetings2016/SAC07/PDFs/Docs/_English/SAC-07-06a(i)-Dorado-assessment.pdf. Accessed 29 Mar 2018

15. Díaz-Jaimes P, Uribe-Alcocer M, Ortega-Garcia S, Durand JD. Spatial and temporal mitochondrial DNA genetic homogeneity of dolphinfish populations (Coryphaena hippurus) in the eastern central Pacific. Fish Res. 2006;80(2-3):333-8. https://doi.org/10.1016/j.fishres.2006.04.015.

16. Díaz-Jaimes P, Uribe-Alcocer M, Rocha-Olivares A, García-de-León FJ, Nortmoon P, Durand JD. Global phylogeography of the dolphinfish (Coryphaena hippurus): the influence of large effective population size and recent dispersal on the divergence of a marine pelagic cosmopolitan species. Mol Phylogenet Evol. 2010;57:1209-18.

17. Oro MG. El Dorado (C. hippurus y C. equiselis). La Pesca Deportiva en México (por la pesca libre y responsable). 1999. http://www.pesca.orgmx/ articulos/dorado1.html. Accessed 2018.

18. Merten W, Appeldoorn R, Rivera R, Hammond D. Diel vertical movements of adult male dolphinfish (Coryphaena hippurus) in the western central Atlantic as determined by use of pop-up satellite archival transmitters. Mar Biol. 2014;161:1823-34. https://doi.org/10.1007/s00227-014-2464-0.

19. Whitney NM, Taquet M, Brill RW, Girard C, Schwieterman GD, Dagorn L, Holland KN. Swimming depth of dolphinfish (Coryphaena hippurus) associated and unassociated with fish aggregating devices. Fish Bull. 2016;114:426-43.

20. Girard C, Dagorn L, Taquet M, Aumeeruddy R, Peignon C, Benhamou S. Homing abilities of dolphinfish (Coryphaena hippurus) displaced from fish 
aggregating devices (FADs) determined using ultrasonic telemetry. Aquat Living Resour. 2007;20:313-21. https://doi.org/10.1051/alr:2008005.

21. Dempster T, Taquet M. Fish aggregation device (FAD) research: gaps in current knowledge and future directions for ecological studies. Rev Fish Biol Fish. 2004;14:21-42. https://doi.org/10.1007/s11160-004-3151-x.

22. Taquet M, Sancho G, Dagorn L, Gaertner J, Itano D, Aumeeruddy R, Peignon C. Characterizing fish communities associated with drifting fish aggregating devices (FADs) in the Western Indian Ocean using underwater visual surveys. Aquat Living Resour. 2007;20(4):331-41. https://doi. org/10.1051/alr:2008007.

23. Taquet M, Dagorn L, Gaertner JC, Girard C, Aumerruddy R, Sancho G, Itano D. Behavior of dolphinfish (Coryphaena hippurus) around drifting FADs as observed from automated acoustic receivers. Aquat Living Resour. 2007;20:323-30. https://doi.org/10.1051/alr:2008008.

24. Martinez-Rincon RO, Ortega-Garcia S, Vaca-Rodriguez JG. Incidental catch of dolphinfish (Coryphaena spp.) reported by the Mexican tuna purse seiners in the eastern Pacific Ocean. Fish Res. 2009;96:296-302. https:// doi.org/10.1016/j.fishres.2008.12.008.

25. Farrell ER, Boustany AM, Halpin PN, Hammond DL. Dolphinfish (Coryphaena hippurus) distribution in relation to biophysical ocean conditions in the northwest Atlantic. Fish Res. 2014;151:177-90.

26. Furukawa S, Kawabe R, Ohshimo S, Fujioka K, Nishihara GN, Tsuda Y, Nakata H. Vertical movement of dolphinfish, Coryphaena hippurus, as recorded by acceleration data-loggers in the northern East China Sea. Environ Biol Fishes. 2011;92(1):89-99. https://doi.org/10.1007/s1064 1-011-9818-y.

27. Hernández-Tlapale C, Ketchum JT, Marín-Enríquez E, Muhlia-Melo A. Horizontal and vertical movements of the common dolphinfish (Coryphaena hippurus) in La Paz Bay, Mexico. Cienc Mar. 2015;41(4):283-95. https://doi. org/10.7773/cm.v41i4.2560.

28. Lin SJ, Musyl MK, Wang SP, Su NJ, Chiang WC, Lu CP, Tonoe K, Wu CY, Sasaki A, Nakamura I, Komeyama K, Kawabe R. Movement behavior of released wild and farm-raised dolphinfish Coryphaena hippurus tracked by pop-up satellite archival tags. Fish Sci. 2019;85:779. https://doi. org/10.1007/s12562-019-1334-y.

29. PRODUCE. 2016. Plan de Acción Nacional para la Conservación y Manejo del recurso Perico en el Perú (PAN-Perico), Resolución Viceministerial Nº1.2016. PRODUCE/DVPA, Lima, Perú.

30. Zúñiga Flores MS, Ortega-García S, Klett-Traulsen A. Interannual and seasonal variation of dolphinfish (Coryphaena hippurus) catch rates in the southern Gulf of California, Mexico. Fish Res. 2008. https://doi. org/10.1016/j.fishres.2008.06.003.

31. Hammann MG, Palleiro-Nayar JS, Sosa-Nishizaki O. The effects of the 1992 El Niño on the fisheries of Baja California, Mexico. Cal Coop Ocean Fish. 1995;1995(36):127-33.

32. Norton JG, Crooke SJ. Occasional availability of dolphin, Coryphaena hippurus, to southern California commercial passenger fishing vessel anglers: observations and hypotheses. Cal Coop Ocean Fish. 1994;35:230-9.

33. Norton JG. Apparent habitat extensions of dolphinfish (Coryphaena hippurus) in response to climate transients in the California Current. Sci Mar. 1999;63(3-4):239-60. https://doi.org/10.3989/scimar.1999.63n3-4261.

34. Alejo-Plata C, Díaz-Jaimes P, Salgado-Ugarte IH. Sex ratios, size at sexual maturity, and spawning seasonality of dolphinfish (Coryphaena hippurus) captured in the Gulf of Tehuantepec, Mexico. Fish Res. 2011;110:207-16. https://doi.org/10.1016/j.fishres.2011.04.008.

35. Oxenford H, Hunte W. Feeding habits of the dolphinfish (Coryphaena hippurus) in the eastern Caribbean. Sci Mar. 1999;63:303-15.

36. Hemphill H. Conservation on the high seas-drift algae habitat as an open ocean cornerstone. Parks. 2005;15(3):48-56.

37. Furukawa S, Tsuda Y, Nishihara GN, Fujioka K, Ohshimo S, Tomoe S, Nakatsuka N, Kimura H, Aoshima T, Kanehara H, Kitagawa T, Chiang WC, Nakata
$H$, Kawabe R. Vertical movements of Pacific bluefin tuna (Thunnus orientalis) and dolphinfish (Coryphaena hippurus) relative to the thermocline in the northern East China Sea. Fish Res. 2014;14:86-91.

38. Marín-Enríquez E, Seoane J, Muhlia-Melo A. Environmental modeling of occurrence of dolphinfish (Coryphaena spp) in the Pacific Ocean off Mexico reveals seasonality in abundance, hot spots and migration patterns. Fish Oceanog. 2018;27:28-40. https://doi.org/10.1111/fog.12231.

39. Yoshida-Hernández H. Variabilidad ambiental y su efecto en la distribución espacio-temporal de las tasas de captura de dorado (coryphaena hippurus) en la región de los Cabos B.C.S., México [thesis], Ciencias Marinas del Instituto Politécnico Nacional, La Paz, Mexico. 2015.

40. Santana-Henández H, Ortega-Garcia S, Valdez-Flores JV. Variación espacio-temporal de las capturas incidentales de dorado (Coryphaena hippurus) en el Pacífico Central mexicano. El Vigia. 2011; 16(39).

41. Braun CD, Galuardi B, Thorrold SR. HMMoce: an R package for improved geolocation of archival-tagged fishes using a hidden Markov method. Methods Ecol Evol. 2018;9(5):1212-20. https://doi.org/10.1111/2041210X.12959.

42. Thys TM, Ryan JP, Dewar H, Perle CR, Lyons K, O'Sullivan J, Farwell C, Howard MJ, Weng KC, Lavaniegos BE, Gaxiola-Castro G, Miranda-Bojorquez LE, Hazen EL, Bograd SJ. Ecology of the Ocean Sunfish, Mola mola, in the southern California current system. J Exp Mar Biol Ecol. 2015;471:64-76. https://doi.org/10.1016/j.jembe.2015.05.005.

43. Basson M, Bravington MV, Hartog JR, Patterson TA. Experimentally derived likelihoods for light-based geolocation. Methods Ecol Evol. 2016;7(8):980-9.

44. Perle CR. Transpacific migrations of Pacific bluefin tuna. In: Movements and migrations of manta rays, pacific bluefin tuna, and white sharks: observations and insights at the intersection of life history strategy and marine ecosystem structure [dissertation]. Palo Alto, CA, Stanford University. 2011.

45. Uchiyama J, Boggs C. Length-weight relationships of Dolphinfish, Coryphaena hippurus, and Wahoo, Acanthocybium solandri: seasonal effects of spawning and possible migration in the Central North Pacific. Mar Fish Rev. 2006;68(1-4):19-29.

46. Matlab. version 9.0.0341360. Natick, Massachusetts: The MathWorks Inc; 2016.

47. Wildlife Computers. Location processing (GPE3 \& Fastloc) in the wildlife computers data portal user guide. 2018. https://static.wildlifecompute rs.com/manuals/Location-Processing-User-Guide.pdf. Accessed 17 May 2019.

48. Mager EM, Esbaugh AJ, Stieglitz JD, Hoenig R, Bodinier C, Incardona JP, Scholz NL, Benetti DD, Grosell M. Acute embryonic or juvenile exposure to deepwater horizon crude oil impairs the swimming performance of Mahi-Mahi (Coryphaena hippurus). Environ Sci Technol. 2014;48(12):7053-61.

49. Stieglitz JD, Mager EM, Hoenig R, Benetti DD, Grosell M. Impacts of deepwater horizon crude oil exposure on adult Mahi-Mahi (Coryphaena hippurus) swim performance. Environ Toxicol. 2016;35(10):2613-22. https ://doi.org/10.1002/etc.3436.

50. Kara AB, Rochford PA, Hurlburt HE. An optimal definition for ocean mixed layer depth. J Geophys Res. 2010;105(C7):16803-21.

51. Reynolds RW, Smith TM, Liu C, Chelton DB, Casey KS, Schlax MG. Daily high-resolution-blended analyses for sea surface temperature. J Clim. 2007;20:5473-96.

\section{Publisher's Note}

Springer Nature remains neutral with regard to jurisdictional claims in published maps and institutional affiliations. 